University of Nebraska - Lincoln

DigitalCommons@University of Nebraska - Lincoln

Biological Systems Engineering: Papers and

Publications

Biological Systems Engineering

$5-3-2008$

\title{
Methods to prioritize placement of riparian buffers for improved water quality
}

\author{
M. D. Tomer \\ USDA/ARS \\ Michael G. Dosskey \\ USDA/FS National Agroforestry Center \\ Michael R. Burkart \\ USDA/ARS
}

Matthew J. Helmers

lowa State University, mhelmers@iastate.edu

Dean E. Eisenhauer

University of Nebraska-Lincoln, deisenhauer1@unl.edu

Follow this and additional works at: https://digitalcommons.unl.edu/biosysengfacpub

Part of the Biological Engineering Commons

Tomer, M. D.; Dosskey, Michael G.; Burkart, Michael R.; Helmers, Matthew J.; and Eisenhauer, Dean E., "Methods to prioritize placement of riparian buffers for improved water quality" (2008). Biological Systems Engineering: Papers and Publications. 3.

https://digitalcommons.unl.edu/biosysengfacpub/3

This Article is brought to you for free and open access by the Biological Systems Engineering at DigitalCommons@University of Nebraska - Lincoln. It has been accepted for inclusion in Biological Systems Engineering: Papers and Publications by an authorized administrator of DigitalCommons@University of Nebraska Lincoln. 


\title{
Methods to prioritize placement of riparian buffers for improved water quality
}

\author{
Mark D. Tomer · Michael G. Dosskey • Michael R. Burkart • David E. James • \\ Matthew J. Helmers · Dean E. Eisenhauer
}

\begin{abstract}
Agroforestry buffers in riparian zones can improve stream water quality, provided they intercept and remove contaminants from surface runoff and/or shallow groundwater. Soils, topography, surficial geology, and hydrology determine the capability of forest buffers to intercept and treat these flows. This paper describes two landscape analysis techniques for identifying and mapping locations where agroforestry buffers can effectively improve water quality. One technique employs soil survey information to rank soil map units for how effectively a buffer, when sited on them, would trap sediment from adjacent cropped fields. Results allow soil map units to be compared for relative effectiveness of buffers for improving water quality and, thereby, to prioritize locations for buffer establishment. A second technique uses topographic
\end{abstract}

M. D. Tomer $(\square) \cdot$ M. R. Burkart · D. E. James USDA/ARS National Soil Tilth Laboratory, 2110 University Blvd., Ames, IA 50011, USA e-mail: mark.tomer@ars.usda.gov

M. G. Dosskey

USDA/FS National Agroforestry Center, Lincoln, NE, USA

M. J. Helmers

Department of Agricultural and Biosystems Engineering, Iowa State University, Ames, IA, USA

D. E. Eisenhauer

Department of Biological Systems Engineering, University of Nebraska, Lincoln, NE, USA and streamflow information to help identify locations where buffers are most likely to intercept water moving towards streams. For example, the topographic wetness index, an indicator of potential soil saturation on given terrain, identifies where buffers can readily intercept surface runoff and/or shallow groundwater flows. Maps based on this index can be useful for site-specific buffer placement at farm and small-watershed scales. A case study utilizing this technique shows that riparian forests likely have the greatest potential to improve water quality along firstorder streams, rather than larger streams. The two methods are complementary and could be combined, pending the outcome of future research. Both approaches also use data that are publicly available in the US. The information can guide projects and programs at scales ranging from farm-scale planning to regional policy implementation.

Keywords Conservation planning - Conservation practices · Non-point pollution - Soil survey ·

Terrain analyses

\section{Introduction}

Establishment of riparian buffers has been encouraged and financially supported by agricultural policies in the US, partly because riparian vegetation has the potential to improve water quality. Many field-scale studies have shown buffers can improve 
water quality, and this literature is well reviewed (e.g., Fennessy and Cronk 1997; Dosskey 2001). Yet at watershed scales, where public concern about water quality is focused, the water quality impacts of conservation practices (such as buffers) are difficult to establish. Therefore, efforts are underway to document benefits from practices supported by public funds (Mausbach and Dedrick 2004). This will be difficult, largely because the efficacy of riparian buffers in controlling non-point pollution depends on location. A number of soil and landscape processes influence the movement of water across or beneath riparian zones towards a stream or river, and these processes all vary in time and space. Riparian buffers are installed to modify these processes in a way that can improve water quality, most typically by slowing water movement, trapping sediment, encouraging infiltration, increasing nutrient uptake and storage, increasing transpiration, and promoting denitrification in the shallow subsurface. However opportunities to alter these processes through management are not the same everywhere.

Buffer design and species selection are influenced by environmental and other management objectives including wildlife habitat or agroforestry production. This paper is focused on environmental benefits. Buffers intended to trap sediment and associated pollutants from runoff typically should include grass (Lyons et al. 2000), perhaps as part of a multi-species buffer with trees (Lee et al. 2000). Including trees in buffers can influence shallow groundwater flow through increased transpiration, even in temperate climates (Komor and Magner 1996; Wagner and Bretschko 2003). Also riparian trees help reduce or denitrify groundwater nitrate (Haycock and Pinay 1993), and provide a range of benefits to aquatic ecosystems (Harper et al. 1999). Studies on environmental effects of harvesting trees in riparian buffers are also published (Hubbard and Lowrance 1997; Liquori 2006).

This paper is focused on prioritizing locations for installing riparian buffers on agricultural landscapes for water quality benefits. If buffers are to be installed where they will have the greatest impact on water quality, then managers need techniques to help them identify these locations. The idea of targeting conservation practices to optimize their effectiveness is not new, and has been discussed in the literature for at least 20 years (Maas et al. 1985). Although examples in the research literature are rare, these types of assessments have been successfully applied at scales ranging from national (Johansson and Randall 2003) to individual landscapes (Bren 1998). However, methods to prioritize locations for buffer establishment using publicly available data across broad areas are still needed. In this paper, we present two techniques for using soil survey and digital terrain data to identify priority locations for attaining water quality benefits of riparian buffers. Location obviously influences buffer design; for this discussion we abridge these considerations by assuming that buffers intercepting surface runoff will include a grass strip (Lee et al. 2000), and that buffers intended to influence shallow groundwater will include trees.

\section{Soil survey technique}

Soil surveys map the locations of various soil types across agricultural landscapes. The US Department of Agriculture's National Soil Survey contains data on soil and topographic characteristics that are important determinants of a buffer's capacity to filter pollutants from agricultural runoff. This technique applies a simple model to rank each soil type for the capacity of a buffer located on it to trap sediment delivered in surface runoff from a cultivated field. Then a map is prepared to highlight the soil types where buffers will perform relatively better. This method ranks and maps all farmable soil types across the landscape, including riparian zones. The rankings of soil types could therefore be applied to riparian and other vegetative practices such as contour buffers, field borders, and filter strips that function to filter surface runoff from cropped fields. Slope, soil texture, and soil erodibility are the key soil attributes used in this technique.

\section{Method}

A two-step model was developed for sediment trapping by buffers. First, an empirical equation calculates a factor for each soil map unit based on soil and slope information contained in a soil survey. Then, a calibration equation converts the empirical factor into an estimate of sediment trapping efficiency of a buffer placed in that soil map unit (Dosskey et al. 2006). 
The first equation obtains a sediment factor (SF), and is based on information provided by a soil survey and utilizes parts of the Revised Universal Soil Loss Equation (RUSLE; Renard et al. 1997):

$$
\mathrm{SF}=\mathrm{D}_{50} / \mathrm{R} \mathrm{K} \mathrm{L} \mathrm{S}
$$

where $\mathrm{D}_{50}$ is the median particle diameter of the surface soil, and R, K, L and S are rainfall and runoff erosivity, soil erodibility, slope length, and slope steepness factors from RUSLE, respectively. All these variables are in imperial units as given by Renard et al. (1997). The value for $\mathrm{D}_{50}$ is assigned based on texture of the surface soil according to Table 1; $\mathrm{R}$ is obtained from the map in Figure 2-1 of Renard et al. (1997); K (without rock fragments) is obtained from tables in a USDA soil survey; L and S are computed according to Renard et al. (1997) for a $200 \mathrm{~m}$ field length using the mean of the slope range given for the map unit in the soil survey.

The calibration equation uses the SF value to estimate Sediment Trapping Efficiency (STE, or

Table 1 Values for median particle diameter $\left(D_{50}\right)$ used for calculating the sediment factor in Eq. 1, estimated based on soil texture (from Muñoz-Carpena and Parsons 2000)

\begin{tabular}{ll}
\hline Soil texture class & $\mathrm{D}_{50}(\mathrm{~mm})$ \\
\hline Clay & 0.023 \\
Silty clay & 0.024 \\
Sandy clay & 0.066 \\
Silty clay loam & 0.025 \\
Clay loam & 0.018 \\
Sandy clay loam & 0.091 \\
Silt & 0.019 \\
Silt loam & 0.027 \\
Loam & 0.035 \\
Very fine sandy loam & 0.035 \\
Fine sandy loam & 0.080 \\
Sandy loam & 0.098 \\
Coarse sandy loam & 0.160 \\
Loamy very fine sand & 0.090 \\
Loamy fine sand & 0.120 \\
Loamy sand & 0.135 \\
Loamy coarse sand & 0.180 \\
Very fine sand & 0.140 \\
Fine sand & 0.160 \\
Sand & 0.170 \\
\hline & 0.200 \\
\hline
\end{tabular}

percent of input load deposited in a buffer), a key output variable from the Vegetative Filter Strip Model (VFSMOD; Muñoz-Carpena and Parsons 2000). The VFSMOD model is a field-scale, single-event mathematical model that is based on the hydraulics of flow and processes of sediment transport and deposition, and has been validated under a range of conditions (e.g., see Munoz Carpena et al. 1999; Abu-Zreig et al. 2001). Values of SF and STE were calculated for 24 combinations of soil texture, slopes, rainfall amounts representing a wide range of cultivated lands in the eastern US (Fig. 1). In calculating STE, a reference set of conditions was assumed that includes a $12 \mathrm{~m}$ wide grass buffer below an adjacent 200 m-long slope, which is cropped and managed with contour tillage and moderate residue. Also, a 2-year frequency, 24-h rainfall event for that location and wet antecedent soil conditions were assumed. A regression between SF and STE gave the following result (Dosskey et al. 2006):

$\mathrm{STE}=100-85 \mathrm{e}^{-1320(\mathrm{SF})}$

This regression equation allows soil survey information to be converted to STE, a mechanistic variable that is useful to interpret a buffer's capacity to trap sediment. This generally depends on both the capacity of the buffer zone to promote deposition at a given site and the magnitude of the runoff load (Dosskey 2001; Helmers et al. 2002). The excellent regression result $\left(R^{2}=0.94\right)$ occurred because SF accounts for

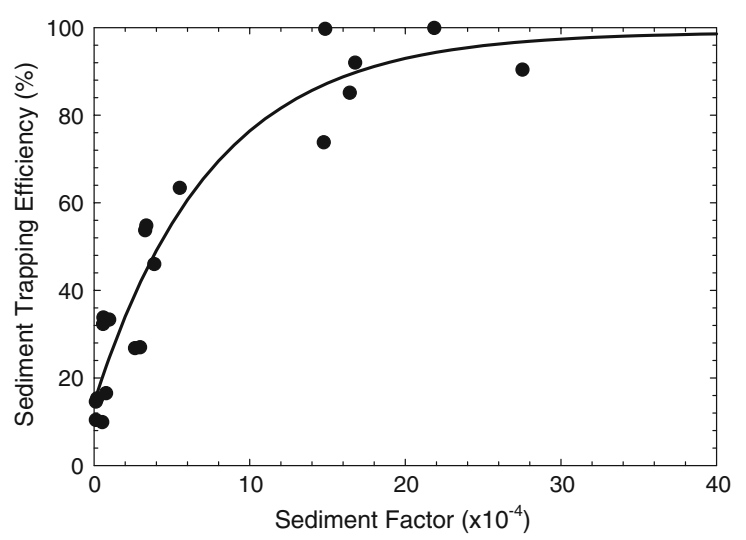

Fig. 1 Comparison of sediment factor values and corresponding values for sediment trapping efficiency (percent of input load deposited in the buffer) (Dosskey et al. 2006) estimated using VFSMOD (Muñoz-Carpena and Parsons 2000). The fitted curve is given by Eq. 2 
the major variables that determine field runoff load and a buffer's sediment-trapping capacity. Application of the results, however, is not necessarily intuitive. Indeed, coarser-textured soils on flatter slopes might result in $100 \%$ buffer effectiveness by completely infiltrating runoff and readily depositing coarse sediment particles. Yet, further analysis using VFSMOD has shown that buffers placed in areas where risks of runoff and sediment generation are greatest trap the greatest amount of sediment, even though proportional efficiency may be smaller (Dosskey et al. 2006). Thus, when buffers are placed below erodible soils and steeper slopes they may have a low trapping efficacy, but they can better protect surface waters from critical areas of sediment generation. This concept is illustrated below.

\section{Application}

This technique is used by computing one value for sediment trapping efficiency (STE) for each soilsurvey map unit in the area of interest using Eqs. 1 and 2. A difference between soil map units reflects intrinsic soil and slope conditions that affect sediment trapping by a buffer. These results can be used to base different recommendations for management in each soil map unit (Dosskey et al. 2006).

For example, two soil map units in a small watershed in northwestern Missouri (Fig. 2), "Grundy Silt Loam, 2-5\% slopes" and "Shelby Loam, 9$14 \%$ slopes" have estimated STE values of $62 \%$ and $29 \%$, respectively. The higher value for the Grundy soil is mainly because its flatter slopes produce smaller runoff loads and promote greater sediment deposition than steeper slopes of the Shelby soil. Based on these results, a manager may recommend priority buffer installation on the Shelby soil because it is a greater source of sediment and a buffer will trap a greater amount of sediment than a similar buffer on the Grundy soil. Alternatively or in addition to placement decisions, a manager may assign relatively wider buffers to locations having Shelby soil in order to enhance the estimated trapping efficiency as well as increase the amount of sediment trapped in these critical areas of sediment generation. Optimal sites
Fig. 2 Sediment trapping efficiency of buffers under reference conditions for soil map units in the CameronGrindstone watershed ( 25 sq. mi; 6475 ha) in northwestern Missouri (Dosskey et al. 2006). Nonagricultural soils were not classified (i.e., soils not meeting criteria). Note that the political (county) boundary, which runs eastwest through the middle of the watershed, influences this classification

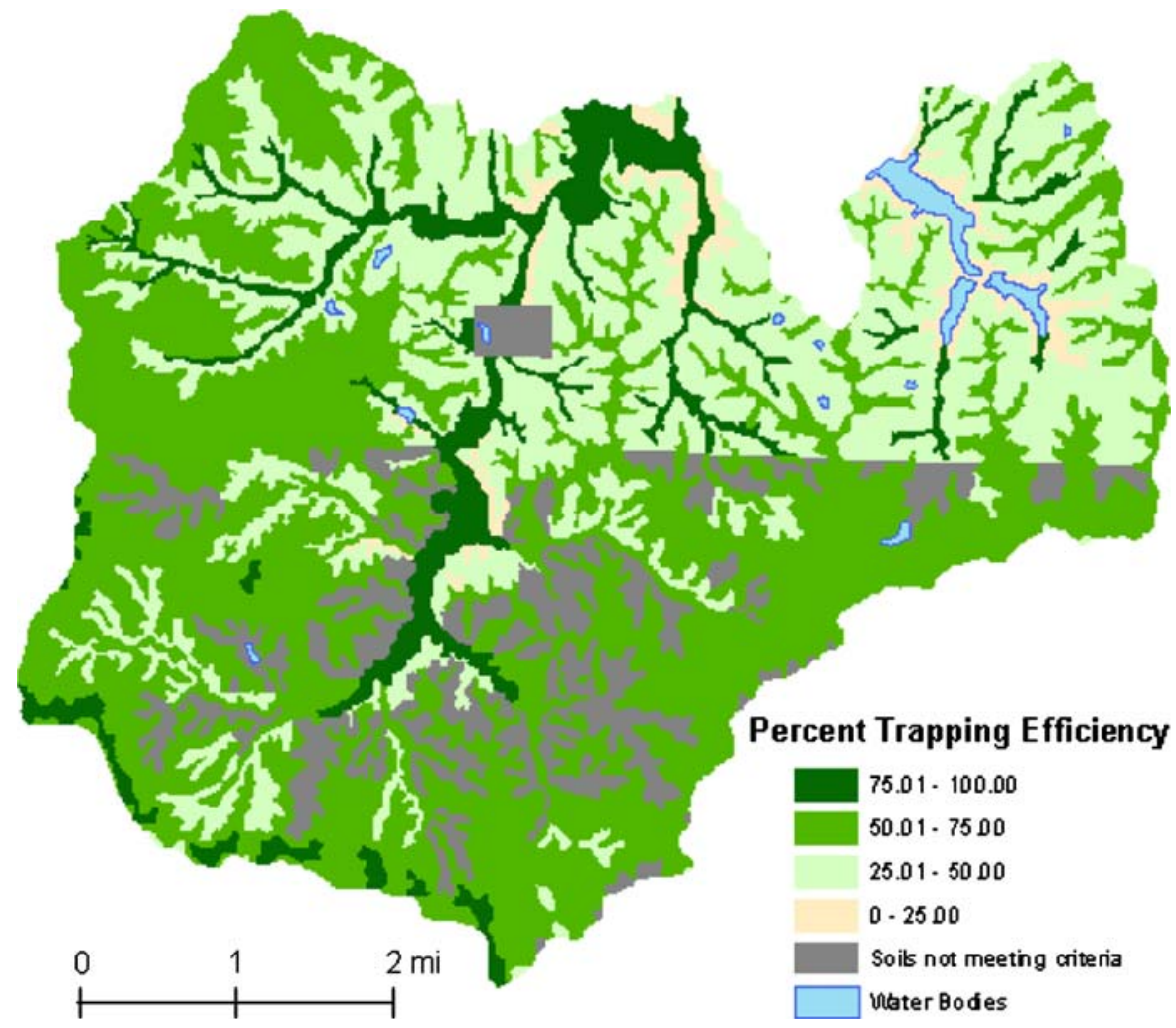


and design recommendations for other practices such as within-field filter strips could be determined using these maps as well. The soil map covering this watershed (Fig. 2) was produced using the SSURGO digital soil survey with geographic information system software (ArcInfo Version 9.1, ESRI, Redlands CA). The map conveniently illustrates how widely buffer performance may vary across this watershed and can be used to locate areas having Shelby soils and others with relatively low sedimenttrapping efficiencies. There are some differences due to slope and land-use interpretations between the two counties that occupy the watershed, which would need to be considered in watershed planning. Among other spatial patterns, the map also shows a network of flat riparian valleys where soils have large STE values. Where these riparian soil types occur immediately below soil types with small STE values may identify the best targeting opportunities in the watershed for water quality improvement. Information on depth to groundwater and extent of hydric soil conditions is also available from soil survey, which could help determine buffer design alternatives and opportunities to influence shallow groundwater by including trees in the buffer.

\section{Terrain analysis technique}

The National Elevation Database (USGS 2004) is a 30-m raster topographic map for the entire United States. These digital elevation model (DEM) data are derived from digitized quadrangle maps, which are typically at 1:24000 scale, similar to soil survey maps. USGS (2004) provide metadata on map sources, and Tomer et al. (2003) summarize sourcemap implications for data quality. Digital terrain analyses (Moore et al. 1991) can be applied to determine a range of landform parameters such as slope, aspect, upslope contributing area, and others that are defined below. Mapping these parameters provides images that reveal pathways of water movement and areas of water accumulation on the landscape. These maps can be classified and interpreted to identify priority sites for riparian buffers. These analyses have been applied to identify priority stream reaches (Burkart et al. 2004), and specific riparian zones for field-level planning (Tomer et al. 2003).

\section{Methods}

These analyses rely on the two terrain variables of slope $\left(\beta\right.$, in degrees) and specific catchment area $\left(\mathrm{A}_{\mathrm{s}}\right.$, units of $\left.\mathrm{m}^{2} \mathrm{~m}^{-1}\right)$. The specific catchment area is the upslope area that can potentially contribute surface runoff to a grid-cell location, per width of flow (interpreted as grid-cell width), and is illustrated in Fig. 3. The calculation of $A_{s}$, for a raster coverage of topography, depends on the direction of overland flow between adjacent cells. For this work, flow directions were determined using the D- $\infty$ method (Tarboton 1997) with software by D.G. Tarboton ( http://www.engineering.usu.edu/dtarb/). This method proportions the upslope contributing area at each cell to two adjacent down-gradient cells according to the aspect (or direction of steepest descent; see Tarboton 1997). The $\beta$ and $A_{s}$ variables are used to calculate compound hydrologic indices (Moore et al. 1991) that can be interpreted in terms of relative buffer effectiveness.

Compound terrain parameters are defined and interpreted as follows; Fig. 3 depicts example riparian areas where the parameters can be mapped. The discharge index $\left(\delta_{\mathrm{q}}\right)$ estimates the proportional contribution of a riparian grid-cell to the total stream discharge using contributing area ratios. That is, $\delta_{\mathrm{q}}$ is the ratio of the riparian-cell contributing area to the watershed area of the stream $\left(\mathrm{A}_{\mathrm{w}}\right)$ at that location.

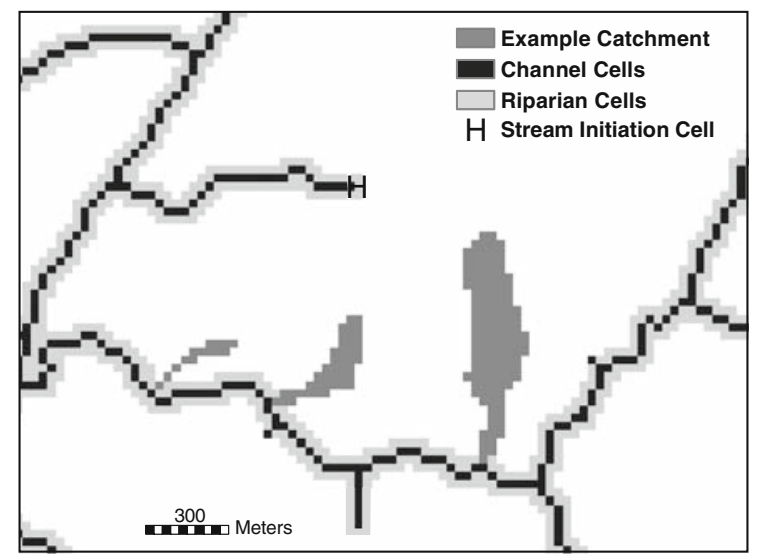

Fig. 3 Examples of riparian catchments, channel cells, and riparian cells using 30-m cells in part of Keg and Silver Creek basins (Burkart et al. 2004). The 'example catchments' indicate the contributing area $\left(\mathrm{A}_{\mathrm{s}}\right)$ for three selected riparian grid cells 
$\delta_{\mathrm{q}}=\left(\mathrm{A}_{\mathrm{s}} / \mathrm{A}_{\mathrm{w}}\right) 1000$

The factor 1000 simply converts the proportion to units of per mille (\%o). Simply interpreted, larger values of this index occur where riparian forest buffers are likely to measurably impact water quality in the stream.

The wetness index (W) is defined as:

$\mathrm{W}=\ln \left(A_{s} / \tan \beta\right)$

This parameter (O'Loughlin 1981; Moore et al. 1991) is used to map areas most prone to soil saturation during rainfall events. Note that $\tan \beta$ converts the slope from degrees to familiar units of topographic rise divided by horizontal distance $(\mathrm{m} / \mathrm{m})$. The $\log$ scale (natural $\log , \ln )$ is used because the ratio $\left(\mathrm{A}_{\mathrm{s}} / \tan \right.$ $\beta$ ) spans many orders of magnitude across landscapes.

Flat areas with large upslope contributing areas are associated with large $\mathrm{W}$ values. Buffers in these areas can remove contaminants from shallow groundwater, and/or filter surface runoff. Filtering of surface runoff can occur where it slows and infiltrates in flat areas below hillslopes. Also, flat riparian areas tend to have shallow groundwater. In both situations, permanent riparian vegetation can benefit water quality. In some instances, however, shallow ground water approaches the surface and limits infiltration of runoff, therefore benefits for surface and subsurface flows may not accrue at all locations with large $\mathrm{W}$ values. Again, grass buffers should work best to remove sediment from runoff, and trees should most effectively influence shallow groundwater.

A sediment transport index $(\tau)$ can be used to locate riparian cells where deposition or erosion is likely (Moore et al. 1991):

$\tau=\left(\mathrm{A}_{\mathrm{s}} / 22.13\right)^{0.6}(\sin \beta / 0.0896)^{1.3}$

where $\beta$ is the slope of the riparian cell (in degrees). Small $\tau$ values occur in riparian areas where overland flow velocities are reduced and sediment can accumulate. The largest $\tau$ values represent erodible conditions and may indicate a need for protective measures such as streambank stabilization.

\section{Application}

Analyses were conducted for Silver and Keg Creek watersheds in western Iowa, and in Tipton Creek in north-central Iowa. In Silver and Keg Creeks, the terrain parameters were averaged along each stream segment, and then classified according to stream order (Strahler 1969). Results of these stream-reach analyses clearly indicate that riparian buffers placed along first-order streams have the greatest potential to improve water quality. Discharge index $\left(\delta_{\mathrm{q}}\right)$ values show that buffers along first-order streams provide significantly $(P<0.05)$ greater opportunities to produce a measurable affect on water quality in adjacent streams than do those along higher-order streams (Fig. 4). Statistical comparisons show significant differences between all stream orders.

Riparian-cells along first-order streams also had significantly larger values of $\mathrm{A}_{\mathrm{s}}$ and $\mathrm{W}(P<0.05)$ than those of larger streams (Fig. 5) in Keg and Silver Creeks. Thus, interception of contaminants in groundwater and/or surface runoff will be most effective along first-order streams. The distributions of $\tau$ values (Fig. 5) show a discontinuous increase with stream order. That is, riparian cells along stream orders one through three have significantly smaller values $(P<0.05)$ than stream orders four and five. Therefore, in these watersheds, riparian areas along smaller

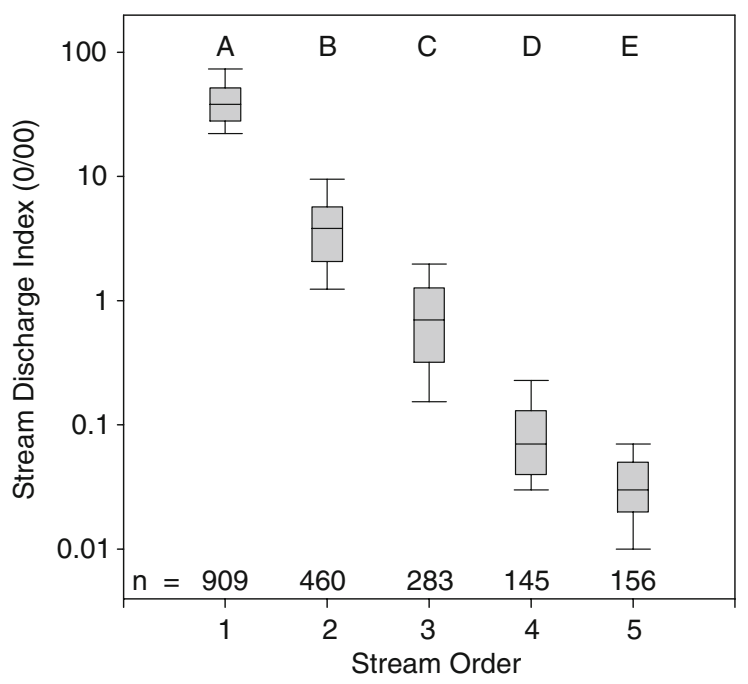

Fig. 4 Mean discharge index $\left(\delta_{\mathrm{q}}\right)$ values for 30-m riparian cells along stream segments in Keg and Silver Creek basins, classified according to stream order. Larger index values along smaller-order streams indicate buffers should most impact stream water quality when placed along headwater reaches. The Y-axis units of per mille (\%o) indicate the area-ratio in thousandths (see Eq. 3). Letters denote that $\delta_{\mathrm{q}}$ for each stream order is statistically different from all other orders at $P=0.05$ (see Burkart et al. 2004) 
Fig. 5 Mean values for wetness index (W, left figure), and sediment transport index $(\tau$, right figure), for 30-m riparian cells along stream segments in Keg and Silver Creek (Burkart et al. 2004). Stream orders sharing a letter are not statistically different $(P>0.05)$

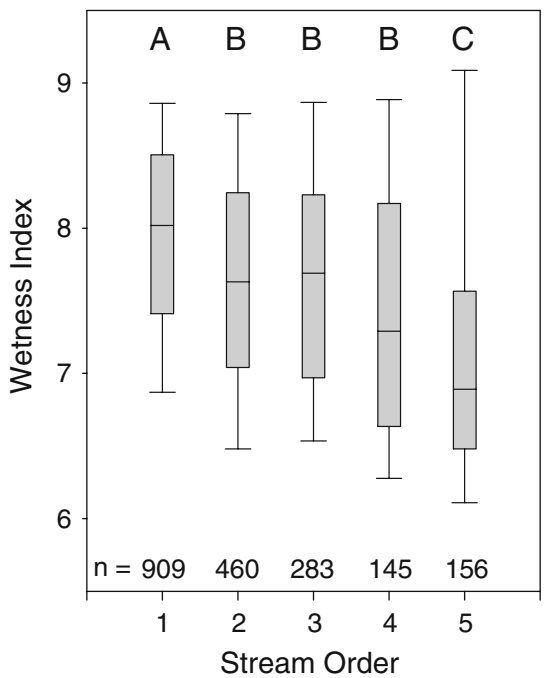

streams provide more deposition sites. Critical sites for erosion protection in riparian areas are indicated along the larger streams with large $\tau$ values (Fig. 5).

Mapping wetness index values of riparian gridcells in Tipton Creek indicates specific riparian zones where runoff or shallow groundwater flows can be intercepted (Fig. 6). Similar maps for $\tau$ also highlighted locations with steep, actively eroding banks. These interpretations were confirmed through a field review with local conservation planners (Tomer et al. 2003). This review also indicated that, although the analysis was conducted at the watershed scale, results were useful for field-scale planning.

\section{Advantages and limitations}

Similar advantages and limitations apply to both types of methods. Both provide a standardized basis for comparing locations across watersheds, states, and regions in the eastern US Soil-survey map units can be one hectare or less, and individual DEM gridcells represent 0.09 ha. Therefore, both techniques can provide detailed spatial resolution. Optimal locations for installing buffers can be located easily by displaying computed results in maps. Calculations and mapping for large areas are readily accomplished using digitized databases for soil survey (USDA Natural Resources Conservation Service 1994) and topography (USGS 2004) in a geographic information system (GIS). Both data sources are freely available to the public. The methods can also be applied at multiple scales, by varying the soil survey data source (i.e., STATSGO or SSURGO), or shifting the focus from individual riparian zones to stream reaches for DEM analyses.

Because simplifying assumptions are used in both methods, and because spatial data sources are not always of uniform quality, these techniques should be used only as a general guide for locating buffers. The soil survey method applies only to controlling sediment runoff from cultivated cropland. For terrainmodeling results, field review is needed to determine whether surface runoff or groundwater may be most influenced by buffers at specific locations (Tomer et al. 2003). This difference has implications for buffer design and management, including tree species selection to meet multiple management goals. Scientific validation of these methods would be challenging in terms of experimental design, but could perhaps be undertaken by a synoptic survey across a range of sites. Results are probably best used as an interpretive tool to target locations where water-quality benefits are likely to accrue, and avoid locations where they are likely to be minimal. Conservation planning inherently involves human judgment; these techniques can inform that judgment but should not supersede it.

\section{Conclusions}

Two ways of identifying priority locations for establishing riparian forest buffers for water quality 


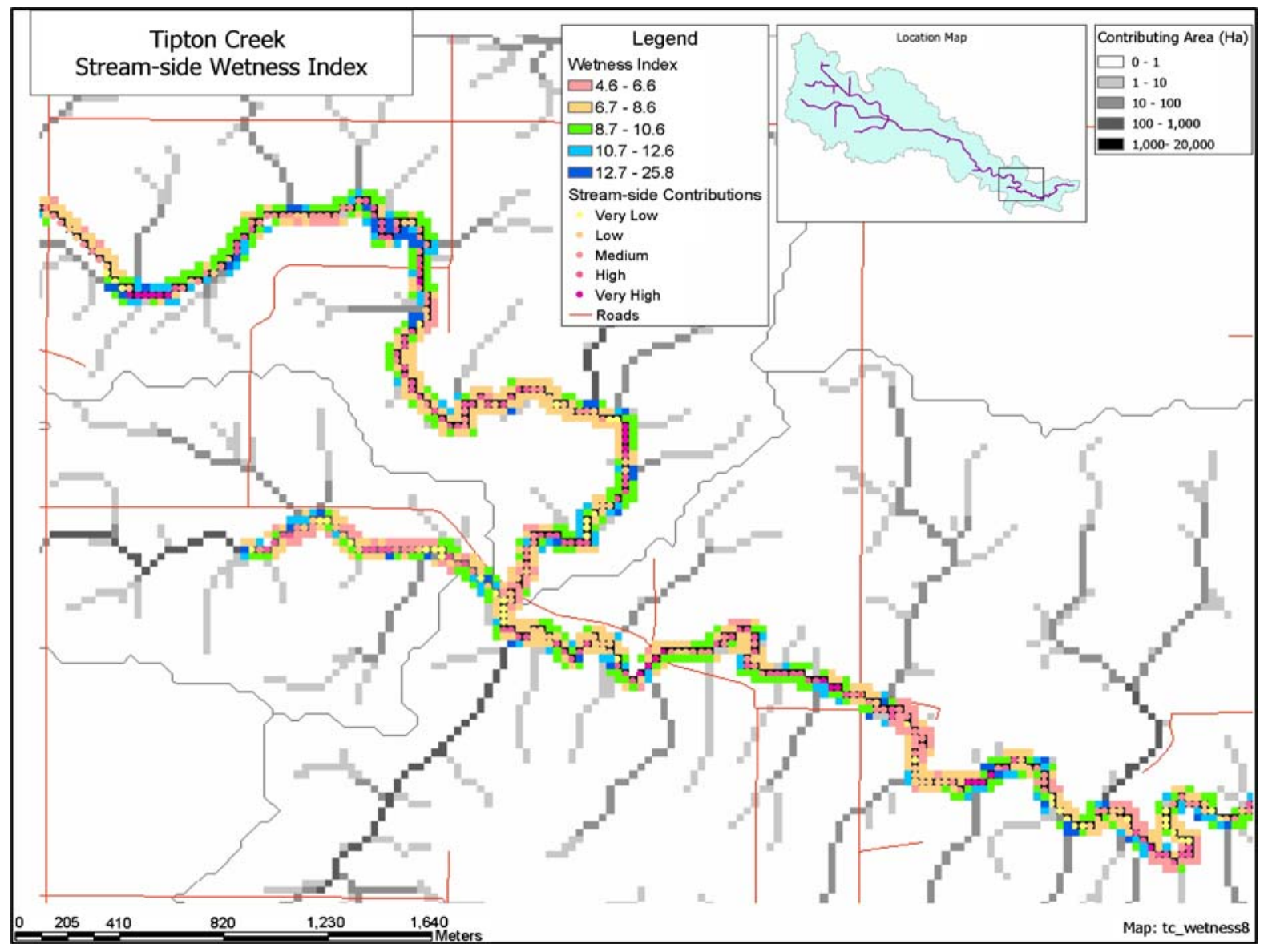

Fig. 6 Map of riparian-cell wetness index values for a part of Tipton Creek (Tomer et al. 2003). Riparian grid cells are shaded to indicate relative opportunities to intercept surface runoff and shallow groundwater with buffer vegetation

improvement have been presented. Both soil survey and terrain data originate from maps created at similar scales (about 1:24,000). Therefore, it may be possible to use these two methods in concert to further enhance buffer planning. The soil survey method identifies where soil properties will best support buffer functioning where runoff can be intercepted. The terrain analysis method identifies where runoff can be intercepted. A combination of these two methods may help planners identify specific locations where buffers can achieve the maximum water-quality impact. Initial work has shown that soil survey and terrain analyses can provide consistent interpretations for conservation planning (Tomer and James 2004). Conclusions from work to date are:

1. Soil survey data can be used to identify locations where buffers can function better to trap sediment and associated pollutants from surface runoff. In general, better locations for buffers are those where slope and soil conditions lead to greater runoff and sediment generation.

2. Terrain analyses can show where buffers will intercept more runoff. Maps generated using terrain analyses have been found interpretively useful for conservation planning. In general, better opportunities to intercept runoff and/or baseflow occur along first order streams than along larger streams.

3. Detailed maps of riparian zones can indicate specific locations best suited for buffers, and can be applied to field-scale planning.

4. Both the soil survey and terrain analysis techniques can be applied at varying scales. General availability of data also allows application in most areas in the United States. 
5. Results depicted in map form, while visually compelling, should only be used as an interpretive aid. Conservation planning requires human judgment, and these decision support tools should only inform that judgment, which must consider site-specific management objectives and design alternatives.

\section{References}

Abu-Zreig M, Rudra RP, Whiteley HR (2001) Validation of a vegetated filter strip model (VFSMOD). Hydrolog Process 15:729-742

Bren LJ (1998) The geometry of a constant-loading design method for humid watersheds. For Ecol Manage 110:113125

Burkart MR, James DE, Tomer MD (2004) Hydrologic and terrain variables to aid strategic location of riparian buffers. J Soil Water Conserv 59(5):216-223

Dosskey MG (2001) Toward quantifying water pollution abatement in response to installing buffers on crop land. Environ Manage 28:577-598

Dosskey MG, Helmers MJ, Eisenhauer DE (2006) An approach for using soil surveys to guide the placement of water quality buffers. J Soil Water Conserv 61:344-354

Fennessy MS, Cronk JK (1997) The effectiveness and restoration potential of riparian ecotones for the management of nonpoint source pollution, particularly nitrate. Crit Rev Environ Sci Technol 27:285-317

Harper DM, Ebrahimnezhad M, Taylor E, Dickinson S, Decamp O, Verniers G, Balbi T (1999) A catchment-scale approach to the physical restoration of lowland UK rivers. Aquatic Conserv: Mar Freshw Ecosyst 9:141-157

Haycock NE, Pinay G (1993) Groundwater nitrate dynamics in grass and poplar vegetated riparian buffer strips during the winter. J Environ Qual 22:273-278

Helmers MJ, Eisenhauer DE, Dosskey MG, Franti TG (2002) Modeling vegetative filter performance. Paper no. MC 02308. Am Soc Agric Eng, St. Joseph, MI

Hubbard RK, Lowrance R (1997) Assessment of forest management effects on nitrate removal by riparian buffer systems. Trans Am Soc Agric Eng 40:383-391

Johansson RC, Randall J (2003) Watershed abatement costs for agricultural phosphorus. Water Resour Res 39(4):np

Komor SC, Magner JA (1996) Nitrate in groundwater and water sources used by riparian trees in an agricultural watershed: a chemical and isotopic investigation in southern Minnesota. Water Resour Res 32:1039-1050
Lee K, Isenhart TM, Schultz RC, Mickelson SK (2000) Multispecies riparian buffers trap sediment and nutrients during rainfall simulations. J Environ Qual 29:1200-1205

Liquori MK (2006) Post-harvest riparian buffer response: implications for wood recruitment modeling and buffer design. J Am Water Resour Assoc 42:177-189

Lyons J, Trimble SW, Paine LK (2000) Grass versus trees: managing riparian areas to benefit streams of central North America. J Am Water Resour Assoc 36:919-930

Maas RP, Smolen MD, Dressing SA (1985) Selecting critical areas for nonpoint source pollution control. J Soil Water Conserv 40:68-71

Mausbach MJ, Dedrick AR (2004) The length we go: measuring environmental benefits of conservation practices. J Soil Water Conserv 59(5):96A-103A

Moore ID, Grayson RB, Larson AR (1991) Digital terrain modeling: a review of hydrological, geomorphological, and biological applications. Hydrol Process 5:3-30

Muñoz-Carpena R, Parsons JE (2000) VFSMOD User's Manual., vol 1.04. North Carolina State University, Raleigh, NC

Munoz Carpena R, Parsons JE, Gilliam JW (1999) Modeling hydrology and sediment transport in vegetative filter strips. J Hydrol 214:111-129

O'Loughlin EM (1981) Saturation regions in catchments and their relations to soil and topographic properties. J Hydrol 53:229-246

Renard KG, Foster GR, Weesies GA, McCool DK, Yoder DC (1997) Predicting soil erosion by water: a guide to conservation planning with the revised universal soil loss equation (RUSLE). Agriculture Handbook No 703. US Department of Agriculture, Washington, DC

Strahler AN (1969) Physical geography, 3rd edn. Wiley, New York

Tarboton DG (1997) A new method for the determination of flow directions and upslope areas in grid digital elevation models. Water Resour Res 33:309-319

Tomer MD, James DE (2004) Do soil surveys and terrain analyses identify similar priority sites for conservation? Soil Sci Soc Am J 68:1905-1915

Tomer MD, James DE, Isenhart TM (2003) Optimizing the placement of riparian practices in a watershed using terrain analysis. J Soil Water Conserv 58(4):198-206

USDA Natural Resources Conservation Service (1994) State soil geographic (STATSGO) data base: Data use information. Misc Pub No 1492. US Department of Agriculture, Washington DC

US Geological Survey (2004) National Elevation Data Set http://seamless.usgs.gov/ cited 30 April 2008

Wagner FH, Bretschko G (2003) Riparian trees and flow paths between hyporheic zone and groundwater in Oberer Seebach, Austria. Intl Rev Hydrobiol 88:129-138 